\title{
Gemifloxacin Mesylate
}

National Cancer Institute

\section{Source}

National Cancer Institute. Gemifloxacin Mesylate. NCI Thesaurus. Code C47548.

The mesylate salt form of gemifloxacin, a synthetic broad-spectrum fluoroquinolone with antibacterial activity. Gemifloxacin mesylate inhibits activities of DNA gyrase and topoisomerase IV, thereby inhibiting DNA replication and eventually bacterial growth. This fluoroquinolone exerts an enhanced spectrum of activity ag ainst gram-positive bacteria such as Streptococcus pneumoniae and Staphylococcus aureus, in addition to its activity against gram-negative bacteria. 